\title{
Comparative Strength of Fibre Reinforced Peat and Clayey-Silt by Using Shredded Scrap-Tire
}

\author{
Norazzlina M. Sa'don ${ }^{1, a^{*}}$, Abdul Razak Abdul Karim ${ }^{1, b}$ \& Siti Noor Linda Taib ${ }^{1, c}$ \\ ${ }^{1}$ Faculty of Engineering, Universiti Malaysia Sarawak (UNIMAS), 94300 Kota Samarahan \\ Sarawak, Malaysia \\ amsazzlin@unimas.my, bakarazak@unimas.my, ctlinda@unimas.my
}

Keywords: Shredded scrap-tire, Fibre-reinforcement, soil stabilization, problematic soils

\begin{abstract}
The strength comparison of fibre reinforced peat and clayey-silt for the compacted subgrade by using the fibre reinforcement technique from the scrap tire is presented. The scrap tires are extracted and shredded into a standard size, i.e., rubber-chip, rubber-crumb, rubber-powder and fibrepolyester for the consistency and homogeneity of the design mix. In this study, two types of fibres are used, which are fibre polyester and rubber crumb. The fibres at various designated percentage are mixed with the clayey-silt and peat with the addition of a minimum $5 \%$ cement content as a binder to achieve the targeted strength. The specimens were prepared by compacting at the optimum moisture content and maximum dry density. The compacted treated specimens were prepared and air cured for 7 and 28 days in room temperature $\left(23^{\circ} \mathrm{C}\right.$ to $\left.26^{\circ} \mathrm{C}\right)$. In evaluating the strength and durability effect of fibres between the untreated (no fibres) and treated specimens (with fibres and cement), the Unconfined Compression Strength (UCS) and California Bearing Ratio (CBR) tests are executed. The findings indicate that the shear strength increases with the curing period. The addition of fibrepolyester and shredded rubber-crumb exhibits an increment in the contact area and bonding between the fibre reinforced materials and soil particles, which then significantly improved the compressive strength of the design mix.
\end{abstract}

\section{Introduction}

The construction of road embankment involves the long-term stability of the road, which is depending on the performance of sub-grade soil. Sub-grade soils mainly serve as a foundation for the pavement to provide adequate support due to traffic loading. The thickness of the pavement varies with different strengths of sub-grade soil that encountered. Due to changes in moisture content and traffic conditions, the durability of pavement come under scrutiny because of the cracking due to severe lateral movement and collapse of road embankment. Proper management and construction practices should be emphasized to overcome the consequential occurrence of differential settlements and ground subsidence problems.

The current practice dealing with soft clay and peat is by simply removing, replacing and displacing the current problematic soil with other good materials/soils in order to increase the strength of the sub-grade road and embankment fill. Nevertheless, it is relatively challenging when deal with deep peat and soft clay of more than $5 \mathrm{~m}$ depth. A variety of soil improvement techniques can be undertaken by improving certain preferred properties of soft clay and peat specifically the dry unit weight, unconfined compressive strength (UCS), California Bearing Ratio (CBR) and swelling characteristic. According to [1], there are numerous soil improvement techniques presented through chemical and mechanical types. However, all these techniques need equipment and qualified workforce to certify the satisfactory performance. Thus, the alternative construction techniques that can be applied is through the soil stabilization/reinforcement procedures by modifying the physical and mechanical geotechnical properties of the origin soil. This method proven to increase the bearing capacity, reduce settlement and lateral deformation. Correspondingly, deliberates to be cost-effective, accessible and environmentally friendly, as the technique comprises the use of waste materials such as scrap tire, fly ash, quarry dust and sawdust [2]. 